\title{
The emergence of integrated private reporting
}

Article

Accepted Version

Atkins, J., Solomon, A., Norton, S. D. and Joseph, N. L. (2015)

The emergence of integrated private reporting. Meditari Accountancy Research, 23 (1). pp. 28-61. ISSN 2049-372X doi: https://doi.org/10.1108/MEDAR-01-2014-0002 Available at https://centaur.reading.ac.uk/38971/

It is advisable to refer to the publisher's version if you intend to cite from the work. See Guidance on citing.

To link to this article DOI: http://dx.doi.org/10.1108/MEDAR-01-2014-0002

Publisher: Emerald

Publisher statement: This article is ( $)$ Emerald Group Publishing and permission has been granted for this version to appear here. Emerald does not grant permission for this article to be further copied/distributed or hosted elsewhere without the express permission from Emerald Group Publishing Limited.

All outputs in CentAUR are protected by Intellectual Property Rights law, including copyright law. Copyright and IPR is retained by the creators or other copyright holders. Terms and conditions for use of this material are defined in the End User Agreement.

www.reading.ac.uk/centaur

\section{CentAUR}


Central Archive at the University of Reading

Reading's research outputs online 
The emergence of integrated private reporting 


\section{Structured Abstract}

Purpose: Private social and environmental reporting (SER) has grown considerably in recent years, consistent with a rise in institutional investor engagement and dialogue with investee companies. We interpret the emergence of integrated private reporting through the lens of institutional logics. We frame the emergence of integrated private reporting as a merging of two hitherto separate and possibly rival institutional logics.

Methodology/Approach: We interviewed 19 companies listed on the FTSE100 and 20 UK institutional investors. The interviews were semi-structured and analysed in an interpretive fashion.

Findings and Implications: We provide evidence to suggest that private SER is beginning to merge with private financial reporting and that, as a result integrated private reporting is emerging. This trend is mirroring the international trend in public reporting toward an integrated approach. Specifically, we find that specialist social responsible investment managers are starting to attend private financial reporting meetings whilst mainstream fund managers are starting to attend private meetings on environmental, social and governance (ESG) issues. Further, senior company directors are becoming increasingly conversant with ESG issues. We interpret our findings as two possible scenarios: (i) there is a genuine hybridisation occurring in UK institutional investment such that integrated private reporting is emerging, or; (ii) the financial logic is absorbing and effectively neutralising the responsible investment logic.

Originality: This is the first research investigating the evolution of private integrated reporting.

Keywords: institutional investment; integrated private reporting; private social and environmental reporting (SER); private financial reporting; institutional logics; paradigm shift. 


\section{Introduction}

Prior literature and observation of policy/practice suggest substantial change in UK institutional investment in recent years. Private communication channels have evolved in the form of private financial reporting, ${ }^{1}$ spurred on by the UK agenda for corporate governance reform initiated by the Cadbury Report (1992). These meetings have tended to focus entirely on financial issues and have represented a way for shareholders to encourage companies to embody beliefs and behaviours consistent with shareholder value (Roberts, Sanderson, Barker and Hendry, 2006). Thus, the process of engagement and dialogue between investors and investees has been preoccupied by financial issues. A strand of academic literature bears witness to the emergence of a parallel, potentially rival, form of institutional investor engagement, namely 'responsible investment'. Earlier forms of responsible investment referred to as 'ethical investment', socially responsible investment, et al., represented a marginal area of dedicated fund management where portfolios were positively and/or negatively screened according to ethical principles. ${ }^{2}$ These forms have evolved into a 'best in sector' investment strategy where no industry is excluded but investors concentrate on the 'best' performers within industries according to environmental, social and governance (ESG) criteria. This relatively new strategic departure epitomises what is now termed 'responsible investment' and has allowed consideration of ESG issues to be applied across mainstream investment portfolios. ${ }^{3}$

One mechanism of responsible investment is private social and environmental reporting (SER), involving one-on-one meetings between companies and their core institutional investors (usually meetings between the corporate social responsibility (CSR) and socially responsible investment (SRI) managers) on ESG issues. ${ }^{4}$ Academic studies suggest that these meetings run in tandem, taking place entirely separately, from one-on-ones on financial issues, i.e. private financial reporting. ${ }^{5} \mathrm{~A}$ recent study adopting a sociological perspective showed that private SER is characterised by significant elements of impression management and that the 'myth' created within the meetings of a responsible investor and a responsible company, by both parties, was more concerned with presenting a front than with genuine

\footnotetext{
${ }^{1}$ Private financial reporting is the term used to refer to one-on-one meetings between institutional investors and their investee companies which focus on financial concerns.

${ }^{2}$ Screening has been defined as, "Avoiding investments in companies that do not reflect an investor's values ... The screening process is the inclusion or exclusion of corporate securities in investment portfolios, supporting companies with strong records in certain screens and avoiding investments in firms that fall short in these areas" (Henningsen 2002, p.163).

${ }^{3}$ This shift in focus and the growth of responsible investment has been noted in the academic and practitioner literature, for example, Ambachtsheer (2005), Friedman and Miles (2002), Mansley (2000), McCann, Solomon and Solomon (2003), Solomon (2002), Solomon, Solomon and Norton (2002) and Sparkes (2002).

${ }^{4}$ There are a host of other mechanisms within the responsible investment process which involve engagement and dialogue on social and environmental issues including investor roadshows, voting and web-based disclosures/blogs and other forms of dialogue with investors and other stakeholders. However there is a growing body of academic literature devoted to the face to face verbal communication between companies and their institutional investors on social and environmental issues and this paper focuses exclusively on the process of private SER.

${ }^{5}$ See Solomon and Solomon (2006) and Solomon, Solomon, Norton and Joseph (2011) for empirical evidence on these separate private SER meetings, their content and role in responsible investment.
} 
accountability (Solomon et al., forthcoming). ${ }^{6}$ In other words, the paper suggested that private SER, although quite well-developed, appears to have little impact on investment decision making.

In the public reporting sphere, until relatively recently, sustainability reporting has also remained generally separate from published financial reporting, mirroring the similar separation in private reporting. However, in the last three years there has been a substantial shift, with the emergence of integrated reporting internationally. The latest triannual survey of corporate responsibility reporting by KPMG (2011) recognized the beginnings of a shift internationally from separate corporate responsibility and sustainability reporting. An integrated report integrates material social and environmental information into the core reporting vehicle, a company's annual report (King Report, 2009; International Integrated Reporting Committee, IIRC, 2011; Solomon and Maroun, 2012). "An integrated report is not simply an amalgamation of the financial statements and the sustainability report. It incorporates, in clear language, material information from these and other sources to enable stakeholders to evaluate the organisation's performance and to make an informed assessment about its ability to create and sustain value.... By its very nature an integrated report cannot simply be a reporting by-product. It needs to flow from the heart of the organisation and it should be the organisation's primary report to stakeholders" (Mervyn King's Foreword, Integrated Reporting Committee of South Africa, IRCSA, 2011, p.1, emphasis added). South Africa, through the publication of the third King Report on Corporate Governance (2009) was the first country to adopt integrated reporting as a listing requirement for the country's stock exchange, the Johannesburg Stock Exchange (JSE) (IRCSA, 2011, Solomon and Maroun, 2012). The IIRC has for some time been working towards recommending and requiring companies worldwide to produce integrated reports (IIRC, 2011; IIRC, 2013). IIRC (2013) explains that integrated reporting emphasises the importance of integrated thinking within an organisation, defining integrated thinking as, “... the active consideration by an organisation of the relationships between its various operating and functional units and the capitals that the organisation uses of affects. Integrated thinking leads to integrated decision-making and actions that consider the creation of value of the short, medium and long term" (IIRC, 2013, p.3).

The findings of a recent study (Solomon and Maroun, 2012) painted a complex picture of the impact of the introduction of integrated reporting on the reporting of social, environmental and ethical (SEE) information in South African companies' annual reports. There was an undeniable increase in the quantity of SEE information reported as a result of King III's requirement. The study found SEE information appears throughout a significantly greater number of sections of the reports for 2010/2011 compared to 2009, before the introduction of IR. However, a striking weakness of the integration of SEE information was significant repetition throughout the reports. The authors suggested that perhaps the reporters were unclear about what an integrated report 'should' look like and what it 'should' include.

\footnotetext{
${ }^{6}$ This paper adopts a framework deriving from the work of Erving Goffman on impression management and theatrical behaviour in face-to-face interaction.
} 
The views of South African institutional investors towards the usefulness of the new integrated reports have been canvassed recently (Atkins and Maroun, 2014). From interviews with 20 members of the South African institutional investment community, the study derived a series of key findings for policy makers which inform the IR agenda, summarised as follows:

(i) The South African institutional investment community welcomes the introduction of IR and, despite identifying concerns and obstacles, they look forward to its development and progress, viewing IR as an improvement in disclosures for investment decision-making.

(ii) The introduction of mandatory IR in South Africa is seen as enhancing significantly South Africa's reputation in global financial markets and competitiveness.

(iii) South African institutional investors identified several areas where they felt IR should be improved: reports should be shorter and less complex, they need to be decluttered; repetition should be avoided; a box-ticking, compliance approach should be avoided.

(iv) Several obstacles to the development of IR were identified including: the need to avoid capture of the agenda by auditors and reporting consultants; the need to avoid impression management by corporate preparers; the need to address lack of financial literacy among trustees of pension funds.

(v) Important recommendations for improving IR were identified including: the need for companies to engage more with their institutional investors on the content of their integrated reports; there should be a drive to raise the awareness of South African asset owners and pension fund trustees towards materiality of ESG issues to their investment portfolios' performance; the need for companies to engage more effectively with their non-financial stakeholders; the need for corporate boards of directors to be more involved in the process of producing integrated reports; the need for an explicit IR framework to be developed to assist preparers; IR should be focused more on broader stakeholder accountability rather than just aimed at shareholders reflecting a more holistic approach to reporting; companies should facilitate continuing financial education for their employees.

This paper seeks to assess the extent to which an integrated approach to reporting is emerging in the private reporting sphere. We interpret the possible emergence of integrated private reporting through the lens of neoinstitutional theory, especially the concept of institutional logics. The dominance of the long-standing finance paradigm of shareholder value and agency theory, which typically excludes 'non-financial' factors may be diminishing. This paper explores whether there are changes within the private SER process, according to the views of the corporate community, which may be symptomatic of a shift in the dominant paradigm underlying financial markets. Private SER, traditionally marginalised within institutional investment may be embedding itself within a short space of time within the heart of mainstream investment activity but there is currently little empirical evidence of such a shift. As private SER and private financial reporting are increasingly frequent and becoming significant areas of corporate accounting and accountability, this paper responds to a call for further research into the coexistence of competing, plural logics especially within the accounting field, "... a focus on institutional rationality in the form of multiple, competing logics can be particularly fruitful. While there has been some good work in this direction, much more needs to be done to understand where logics and new practices come from and how they relate to each other. Accounting provides 
a crucial context to explore these issues and since institutional and practice theories are prevalent perspectives within the community of behavioral accounting researchers, accounting scholars are in a prime position to contribute valuable knowledge to our understanding of the dynamics of institutions and practice" (Lounsbury, 2008, p.358).

Although several studies have investigated the views of institutional investors towards private SER and its evolution, there has been hardly any attempt to canvas the views of the corporate community regarding the usefulness, function, content and evolution of private SER. Solomon and Darby's (2005) study involved interviews with CSR managers from FTSE100 companies but in general studies have focused on institutional investors' views. Institutional investors represent a distinct professional institutional grouping and are therefore an apt focus for investigation into institutional logics but similarly corporates are involved in private SER and represent significant institutions requiring study. Institutions have been defined as supraorganisational patterns of activity by which individuals and organisations produce and reproduce their material subsistence and organise time and space, as well as being symbolic systems, ways of ordering reality, which render time and space meaningful (Friedland and Alford, 1991). Institutions are also thought to be guided by a distinct institutional logic. In this paper we provide evidence pertaining to the evolution of private SER (as a core responsible investment mechanism) to indicate whether the dominant finance logic in institutional investment may be metamorphosing into a broader, holistic logic of investment strategy and decision-making. This paper aims to:

- Interpret the recent evolution of institutional investment and the development of responsible investment through the lens of institutional logics;

- Research the perceptions of representatives from FTSE100 companies and institutional investors, involved directly in private SER regarding its evolution;

- Explore the extent to which an integrated approach is emerging in private reporting

- Refer to neoinstitutional theory and institutional logics to interpret this potential integration.

The remainder of this paper is structured as follows. In section two we discuss existing literature relating to private SER as well as an overview of the practitioner environment and a discussion of relevant theoretical work. In this section we seek to interpret the evolution of responsible investment through the lens of institutional logics. Section three outlines our research method. In section four we present our research findings from interviews with 19 FTSE100 companies and 20 institutional investors and the paper concludes with a discussion in section five.

\section{Prior literature and theoretical framework}

\section{Competing institutional logics}

There is a long history of investigation into the way in which institutions, organisations and society change and shift over time. Institutional theory investigates structural change and shifts in the status quo. A perennial issue addressed by institutional research is the difficulty of overthrowing the status quo, “... actors may overthrow institutional structures (such as organizational forms), rejecting the status quo of how to do things, but underlying patterns of privilege may remain untouched, or even be strengthened-reinforcing the status quo of who benefits" (Greenwood and 
Suddaby, 2006, p.43). Indeed, neoinstitutional theory and institutional logics focus on how, and if, institutional status quo may be transformed. As it has evolved, neoinstitutional theory has shifted from focusing on isomorphism and mimetic change processes to a more multidimensional approach where competing logics and heterogeneity are accepted within organisational models (Lounsbury, 2008; Scott, 2008). This 'new' approach is traced back to Meyer and Rowan's (1977) where perceptions of earlier 'two-stage model' of diffusion and associated notions such as 'institutionalization' and 'isomorphism' being replaced by ntions of institutional environments being more fragmented and contested, influenced by multiple, competing logics" (Lounsbury, 2007). Logics can be competing and diverse, with institutional environments being understood as pluralistic (Meyer and Rowan, 1977). Indeed, the concept of institutional logics has evolved which encompasses competing forms of practice (Lounsbury, 2008, p.353). Logics at the societal level may be the capitalist market, or the nuclear family (Lounsbury, 2008). At the level of industries, logics focus on decision-makers and on a series of issues and solutions (Lounsbury, 2008). Further, institutional logics have been interpreted as cultural beliefs that shape the cognitions and behaviours of actors" (Dunn and Jones, 2010).

Contending logics can fundamentally shape variation in practices and behaviour within an industry. For instance, Lounsbury (2007) examined the spread of contracting to independent professional money management firms among US mutual funds. Mutual fund firms were run according to the logic of trusteeship whereby their main goal was to focus on conservative, long-term investment. Consequently in the mid-20 $0^{\text {th }}$ century mutual funds consisted chiefly of conservatively managed diversified common stock funds. However, the growing dominance of portfolio theory and financial economics ushered in professional money management service firms, leading to the emergence of a performance logic. This new performance logic was characterised by more aggressive investing techniques in order to maximise shortterm returns. Despite the increasing dominance of the performance logic, the trustee logic survived to some extent in the mutual fund industry. The new performance logic was well-established by the 1960s but the competing trustee logic continued to thrive in the 1970s as more passively managed index and other funds emerged.

One of the important issues raised in the literature, relating to competing and coexisting institutional logics is whether the values and mores underlying the different logics are compatible or contradictory. For example, as pointed out by Laughlin et al. (1994), it would be difficult to find two organisational approaches more different from a values perspective than medical care and financial considerations. It is this clash of values which makes hybridisation extremely difficult. The people pioneering each of two competing logics may be espoused to entirely different value systems rendering ant genuine collaboration and eventual merging difficult if not impossible. In financial investment the likelihood that the underlying values of financial, mainstream fund managers and those of SRI managers are potentially miles apart. In terms of the people involved, many of those involved in the SRI 'movement' come from a social/environmental activist background. Conversely, mainstream fund managers tend to come from financial investment training. ${ }^{7}$ Dunn and Jones look at

\footnotetext{
${ }^{7}$ It is interesting that until recently SRI and the consideration of ESG factors have been generally absent from UK academic and professional training programmes. Only relatively recently have ethics, governance and stakeholder accountability begun to be incorporated into professional accounting and financial management qualifications such as ACCA, for example.
} 
the significant role of academic education in developing the competing logics in healthcare. Similarly, the role of professional and academic education in finance/investment/accounting in helping or hindering the advance of SRI cannot be overstated.

Institutional theory has been used extensively within the accounting literature to analyse and interpret changes in organisational structure and policy and the institutional (Lounsbury, 2008). In accounting, institutional theory has been used to interpret resistance to change within organisations as well as organisational change more broadly (Laughlin, 1991; Laughlin et al., 1994; Broadbent et al., 2001). The neoinstitutional framework can be especially useful in analysing institutional developments when change happens suddenly or where there is significant resistance to change from existing institutional bodies or structures. Where there are evolutions in thinking and evidence of shifts in social reality, aspects of neoinstitutional theory can serve to elucidate these changes and enhance understanding. Fiss (2008) expounded on the evolution of institutional theory and emphasised the role of resistance to institutional change.

The concept of institutional logics is frequently applied to the analysis of institutional change and a logic is viewed as the, "socially constructed, historical pattern of material practices, assumptions, values, beliefs, and rules by which individuals produce and reproduce their material subsistence, organize time and space, and provide meaning to their social reality" (Thornton, 2004, p.69). Often, using longitudinal analysis, the evolution of an institutional field is interpreted as the shift from a historically dominant logic to a different, contemporary logic. Historically oriented studies are common (Sine and David, 2003; Blatter, 2003; Castells, 2000; Zijderveld, 2000; Meyer and Hammerschmid, 2006; Green et al., 2008).

Competing logics were shown to co-exist and rivalry between competing logics was found to be managed through the development of collaborative relationships (Reay and Hinings, 2009). Dunn and Jones (2010) showed that multiple, plural logics can coexist, fluctuating over time and creating dynamic tensions. Indeed, they emphasised that institutional change did not necessarily involve the replacement of a dominant logic by another but where professions operate in multiple institutional spheres, plural logics can thrive together. Specifically, they identified two logics central to medical education as the care logic and the science logic which they found to have coexisted over a long period of time. An alternative is the hybridisation of logics where one aspect of a logic is effectively absorbed into a dominant logic as tensions within a profession cannot be sustained over time (Dunn and Jones, 2010; Suddaby and Greenwood, 2005). We now turn to analysing our research questions from the perspective of institutional logics.

\section{Emergence of a 'responsible investment logic'}

Our research shows that the institutional logic of finance, whereby only core financial indicators are considered, has for some time coexisted with a responsible investment logic such that private SER is running in tandem with private financial reporting. Further we seek to discover the extent to which, if at all, private reporting may be adopting an integrated approach, mirroring shifts towards integrated reporting in the public reporting sphere. 
As a normative basis for our enquiry, we posit that the ongoing crisis of climate change and its severe repercussions not merely on the natural environment but on societies and businesses worldwide are unlikely to leave the financial markets untouched. Orthodox models which ignore 'non-financial' matters such as 'the environment', we suggest, may be no longer suitable to economies which are increasingly affected by the symptoms of changing climatic conditions (storms, unpredictable weather patterns, crop shortages, droughts/floods, rising sea levels, governmental pollution/carbon taxes, to name but a few). Financial models relied on for decades by the institutional investment community may no longer suffice in the new century where social and environmental issues are paramount. Similarly, the financial crisis arising from the banking sector demonstrated a failure of the corporate governance system, despite the apparent strength of corporate governance codes of practice and policy documentation. The governance model enshrined in agency theory and shareholder accountability failed to prevent failures in risk management, boardroom ethics and remuneration structures. Shifts in terminology have occurred continuously since the turn of the century in the domain of responsible investment with new terms evolving and superseding each other at a rapid pace. ${ }^{8}$ Investigating the recent evolution of private SER and responsible investment more broadly is crucial to furthering an understanding of the evolution of the financial markets more broadly and to gaining insights into whether the status quo of theoretical finance is steadfast or whether there is a merging of institutional logics.

Recent years have witnessed substantial change within the UK institutional investment industry. We interpret this change through the lens of institutional logics: the emergence of a 'responsible investment logic', coexisting and to some extent rivalling the long-standing 'finance logic' in mainstream institutional investment. The emergent responsible investment logic involves the development of separate but parallel processes such as one-on-one meetings between SRI managers and CSR managers on ESG issues, as well as the emergence of separate SRI analyst branches of the institutional investment industry. We trace this development looking at key events and factors which have contributed to the development of this responsible investment logic.

There is a long history of 'ethical investment' which differs substantially from current responsible investment practice. Ethical investment has been followed for decades (if not centuries) by investors wishing to invest money according to strict ethical principles and involved the management of relatively small, dedicated portfolios and funds which screen out companies according to ethical/green criteria. ${ }^{9}$ The history and performance of purely ethical funds have been well-documented and is not the subject of this paper: we are interested in the evolution of responsible investment which employs a best in sector strategy and has infiltrated mainstream investment

\footnotetext{
${ }^{8}$ Terms such as: ethical investment, socially responsible investment, responsible investment, 'social, ethical and environmental' (SEE), 'environmental, social and governance' (ESG), enhanced analytics, enlightened shareholder value, etc.

${ }^{9}$ The Sullivan Principles were established in the 1800s. Similarly the activities of the Quakers encouraged responsible business practices from the $17^{\text {th }}$ century in the UK.
} 
portfolios. ${ }^{10}$ Therefore our analysis (and Table 1) refer to the emergence of responsible investment in the UK which we gauge from around 1990.

Since around the turn of the century there has been a distinct shift away from screening strategies and towards direct engagement. For example, Friends, Ivory \& Sime around 2000 implemented an engagement approach for social, ethical and environmental (SEE) issues, encouraging companies to listen to their institutional fund managers and make recommended changes to corporate strategy (Litvack, 2002). Another large institutional investor, Morley Fund Management, launched an SRI engagement programme intended to monitor investee companies' SEE behaviour around the turn of the century (Pensions Week, 2002). At a similar point in time, many UK pension funds started to advise their fund managers to adopt an SRI strategy of active engagement. For example, the trustees of the Church of Scotland pension fund were instructed to review the financial implications of the church pension fund's SRI policy and consequently decided to move away from a screening strategy and towards a strategy of engagement with investee companies on SRI issues, as there were fears that screening reduces investment return (Boatright, 1999; Wadsworth, 2002).

Greater engagement and dialogue between institutional investors and their investee companies have been promoted since the Cadbury Report (1992) highlighted the need for the institutional investment community to accept responsibility for corporate governance and discharge accountability to their clients through more active share ownership. The recent Stewardship Code, despite its lack of regulatory backing, provides a solid architecture for the development of more effective engagement and dialogue with a focus on accountability and transparency by institutional shareholders. Further, the Stewardship Code explicitly advises institutional investors to escalate their activism in relation to ESG issues where problems arise within their investee companies. The process of private meetings between companies and their institutional investors represents a core element of engagement and dialogue and an important aspect of institutional investor stewardship. Private SER constitutes a significant part of responsible investment. Historically, responsible investment has been called ethical investment, SRI and consideration of ESG issues. Responsible investment is currently the commonly used term as it is perhaps deemed to have less negative connotations and may be more acceptable to the wider financial and corporate community. Responsible investment is a strategy now adopted by mainstream institutional investors which involves taking ESG considerations into account in the investment decision-making process.

One of the actors instrumental in the process of integration is the United Nations Principles of Responsible Investment (UNPRI). UNPRI has produced six principles to guide responsible investment. UNPRI currently has just over one thousand signatories representing a total of $\$ 30$ trillion dollars of investment which equates to $25 \%$ of global assets (Piani 2011). On average, institutional investors who have signed up to the UNPRI are commonly involved in four campaigns at any point in time, as UNPRI represents a forum for collective action and collaboration between institutional investors. The 2011 Report on Progress (PRI, 2011) found that 94\% of asset owners

\footnotetext{
${ }^{10}$ See, for example, Gregory et al. (1997); Hancock (1999); Harte et al. (1991); Holden-Meehan (1999); Knowles (1997); Luther and Matatko (1994); Luther et al. (1992); Mallin et al. (1995); Williams (1999).
} 
and $93 \%$ of investment managers have a responsible investment policy. ${ }^{11}$ Piani describes UNPRI Clearinghouse as representing a hybrid disclosure process, not public and not private. This hybrid form of social and environmental activism and reporting (Gond and Piani, 2011) is connected to private SER but is not synonymous with it. The collaboration is likely to influence the way in which institutional investors communicate with their investees in private meetings and probably informs the private reporting process to some extent. Overall, the work of UNPRI seems, at least on the surface, a significant move towards integrating ESG issues into the heart of institutional investment and institutional investors' engagement and dialogue with investee companies.

One of the interesting aspects of the development of the PRI and of the responsible investment agenda more broadly is the role of social activists. Indeed, the institutional literature recognises the role of entrepreneurs in instigating new institutional logics and organisational change (Lounsbury, 2001). The founder of the PRI, James Gifford came from an activist background and has been at the forefront of the evolution of a responsible investment logic. Lounsbury (2001) showed how, “...spin-off groups from the ecological movement helped to create a recycling industry and played a key role in the diffusion of recycling programs across US colleges and universities" (Lounsbury, 2008, p.355). A similar phenomenon is evident in SRI. Indeed, research has shown that social movements can have a substantial impact on the development of new industries as well as institutional change (Lounsbury, Ventresca and Hirsch, 2003). ${ }^{12}$ The Student Environmental Action Coalition in the US was central to driving forward recycling programmes in schools. However, there has been relatively little research into the integration of social activists' agendas into mainstream organisations (Giugni, 1998; Giugni, McAdam and Tilly, 1999; Lounsbury, 2001). The role of social activists in the evolution of responsible investment has not been researched but is evident in discussions with members of the SRI community. ${ }^{13}$

A significant feature of responsible investment is the relatively recent evolution of private SER processes. There is a stream of literature which has investigated the evolution of these processes of one-on-one engagement. The majority of academic research into private reporting channels has focused on private financial reporting (Holland, 1998a; 1998b; Holland and Doran, 1998; Holland and Stoner, 1996; Roberts et al., 2006; Solomon and Solomon, 1999). There is a relatively small but expanding body of research into private SER. Friedman and Miles (2001) identified the beginning of a change in attitude within the City of London towards SRI. Solomon (2009) sketched the transformation of SRI from a marginal to a mainstream

\footnotetext{
${ }^{11}$ Not this refers to asset owners and investment managers who are signatories to UNPRI. In 2011 the survey covered 539 respondents managing assets of US\$29.6 trillion.

${ }^{12}$ Lounsbury et al. (2003) found that early social-movement-inspired non-profit recyclers's efforts were ignored but that their activities led to the emergence of the modern recycling industry as, “... they provided a foundation for the successful creation of a new recycling industry since for-profit solid waste conglomerates could rely on the free labour of citizens who continued to clean and sort discards in the spirit of ecological goodwill" (p.96). Further this change led to a new 'for-profit' model. Similarities can be recognised between the influence of social activists on the growth of recycling and of social/environmental activists on the growth of responsible investment.

${ }^{13}$ One of the authors has had many informal meetings and discussions with leading members of the SRI community over the last 15 years and the inspirational and crucial role of certain individuals in driving forward the development of responsible investment is a 'taken-for-granted' known within the this community.
} 
issue within institutional investment. Solomon, Solomon and Norton (2002) provided evidence from a questionnaire survey to show that SRI was being driven by factors internal and external to investment institutions, including an increasing societal interest in social responsibility as well as the activities of special interest groups. Such shifts may be due to a shift in societal expectations (Laughlin, 1987; 1991), "[c] [hange will take place as organisations react to broader changes that impact on the institutional environment in which they exist" (Broadbent et al., 2001, p.571). Solomon and Darby (2005) suggested that private SER represented a process whereby institutional investors and their investee companies were collaborating to create a joint green myth of social and environmental accountability. Such a myth is consistent with institutional change which is cosmetic rather than genuine. Solomon and Solomon (2006) showed from interviews with UK institutional investors that the private SER process was beginning to become more formalised and structured and demonstrated an interplay between private and public SER. Solomon, Solomon, Norton and Joseph (2011) demonstrated an increasing incidence of climate change within the private SER and the way in which climate change is starting to dominate the agenda with respect to other ESG issues. Indeed, climate change represents an increasingly crucial influencing external factor which represents a shock to the institutional investment community. Exogenous shocks which affect society are identified in the literature as factors which can drive institutional change and the emergence of new institutional logics.

We present the emergence of the responsible investment logic by identifying the main factors and events driving its evolution. There are a host of other mechanisms within the responsible investment process which involve engagement and dialogue on social and environmental issues including investor roadshows, voting and web-based disclosures/blogs and other forms of dialogue with investors and other stakeholders. However there is a growing body of academic literature devoted to the face to face verbal communication between companies and their institutional investors on social and environmental issues and shaping this new rival logic within the institutional investment industry in tabular form. Table $1^{14}$ documents the emergence of a responsible investment logic by marking significant events that have encouraged and led to greater engagement by the UK institutional investment community with investee companies on ESG issues. The emergence of responsible investment practices, especially private SER as a form of responsible investment practice represents an emerging logic in institutional investment which has grown in a similar way to the emergence of the performance logic and it threat to the incumbent trustee logic in the mutual fund industry (Lounsbury, 2007). The emergence of the responsible investment logic has led to private SER practices/processes carrying on not in different organisations within the investment industry (as with the existence of different mutual funds) but in parallel with finance-dominated practice in the form of private financial reporting practices. However, the growth of responsible investment has also witnessed a degree of heterogeneity with some institutional investors focusing more heavily on the responsible investment logic and others not e.g. Hermes, Friends Provident, Hendersons as champions of SRI. "Multiple logics can create diversity in practice by enabling variety in cognitive orientation and contestation over which practices are appropriate. As a result, such multiplicity can create enormous

\footnotetext{
${ }^{14}$ Dunn and Jones (2010, p.117) expressed the development of logics of care and science in medical education in tabular form. We use a similar approach to document the emergence of a responsible investment logic in UK institutional investment.
} 
ambiguity, leading to logic blending, the creation of new logics and the continued emergence of new practice variants" (Lounsbury, 2008, p.354).

Insert Table 1 about here

It seems from the existing literature as well as from practitioner studies that there has been a gradual transformation in the attitudes of the UK institutional investment community towards ESG issues and that since the turn of the century increasing attention has been given to these issues within the private reporting context. However, it has remained uncertain whether this transformation has resulted in the genuine integration of ESG issues into private financial reporting and therefore the mainstream investment decision-making process. In other words, private SER may continue to stand separately from private financial reporting, with different actors involved in each set of meetings and little or no joined-up thinking linking the two. Previous research has shown that private SER processes have been growing but suggest that the meetings have been running separately from the mainstream private financial reporting process. In this paper, we analyse the views of the corporate and institutional investor communities towards the private SER process and seek to discover the extent to which private SER is remaining separate or integrating with private financial reporting. We aim to discover whether private reporting is starting to mirror current trends in public reporting by adopting an integrated approach.

\section{Research method}

We conducted 39 interviews with representatives ${ }^{15}$ from companies listed among the FTSE100 and from leading UK investment institutions during 2007 and 2008. In the analysis we have coded the interviewees as $\mathrm{C} 1-19$, to refer to the company interviewees and I1-20 to refer to the institutional investor interviewees. We asked the interviewees a series of questions about their views and experiences of the evolution of the private SER process, directing specific questions to their perceptions of the future of private SER. The interviews were semi-structured and we encouraged interviewees to talk freely and at length in a self-reflective manner. We analysed the interview data interpretively allowing the framework to evolve out of the interviewees' discussions. This interpretive, interview approach to research in finance and especially investigation into private reporting processes has grown in popularity in recent years in the academic accounting and finance literature. ${ }^{16}$ The interview method is also inkeeping with earlier studies of the evolution of institutional logics. The empirical application of institutional logics has implemented interviews as a research tool. For example, Thornton (1999) combined interview data with historical analysis to assess how institutional logics changed from an editorial to a market focus within the Higher Education publishing industry. We use the interview data to examine how the situation described in Table 1 is evolving further. We also analyse

\footnotetext{
${ }^{15}$ These were all CSR/IR (investor relations) managers and SRI managers who were directly involved in private SER.

16 See, for example, Holland (1998a; 1998b), Holland and Doran (1998), Holland and Stoner (1996), Roberts et al. (2006), Solomon and Darby (2005), Solomon and Solomon (2006), Solomon et al. (2011), Solomon et al. (forthcoming).
} 
the data in order to provide a picture of any shift in institutional investment focus from purely financial to a holistic approach where financial and non-financial factors are combined. Similarly, Green et al. (2008) used interviews with corporate board members to examine how competing institutional logics shape institutional fields. Further, we only have interview data from listed companies and it would be informative to ask similar questions of the institutional investment community. There are naturally limitations to the use of interview method as the companies' and investors' public faces within the interview situation may differ from their private face. Although publicly our interviewees may discuss environmental issues, they may not place the same emphasis on these issues within the context of private SER. The focus of the research is on the UK context as this paper represents the culmination of about 15 years' research by the authors into the evolution of responsible investment in the UK.

\section{Interview findings}

Our interviewees provided evidence to support the emergence of a responsible investment logic through the development of private SER. Further, the interviews provided evidence that private SER is gradually merging with private financial reporting. This development seems, from the perceptions of our interviewees and in our interpretation, to represent an increasingly integrated approach to private reporting. The findings are discussed in the following sections: the evolution of a responsible investment logic and private SER (supporting Table 1); merging of private SER with private financial reporting: evidence of a new institutional logic; evidence of resistance to private SER and to the responsible investment logic; perceptions concerning the future of private SER and evidence for the emergence of integrated private reporting.

\section{(i) Evolution of private SER and evidence of the responsible investment logic}

Our discussions with the company and investor interviewees indicated that there were a range of features characterising the emergence of a responsible investment logic and specifically the development of private SER including: the timing of the emergence of private SER; private SER becoming more proactive, more frequent and more mature; the growing perception that social and environmental issues are increasingly perceived as financial issues; increasing frequency of private SER. The investors we interviewed provided a strong business case for responsible investment which demonstrated a best in sector strategy and not a screening strategy, consistent with the development of responsible investment rather than earlier forms of ethical investment,

"we don't do any screening, no negative or positive screening; we really are just high conviction long term investors ... the idea is to pick companies that are good for the planet, good for society, good for health, whatever the issue may be and that ultimately if they're great companies then they will make even better returns for our clients" (I1).

Our interviewees indicated a significant change in private SER over a short period of time and pinpointed the shift in attitude towards private SER within the institutional investment community as around the turn of the century, 
"Well it's changed quite considerably really because if I go back 7 or 8 years, the institutional investors would not want to talk to [company] about anything to do with social or environmental issues at all and we would regularly publish environmental reports at the end of the year for all our operations and they would not want to receive anything, as simple as that" $(\mathrm{C} 1$, emphasis added $)$.

Both the company and the investor interviewees were specific about the ways in which private SER had evolved in recent years and explained how the sophistication and proactive nature of private SER had evolved,

"... initially we were asked a large number of questions over a wide range of subjects and we were very reactive; Where they do engage us we're extremely responsive so we go out of our way to get back to them and to give them the information they want, barring stuff that's commercially confidential. So I think that we've moved from being very reactive to being more proactive and we're in a better place... ... I felt at some stages there was an overreaction and over expectation on the part of... their expectations of the company were unrealistic. I think now the expectations are much more realistic, they're much more understanding of the constraints we're working with and much more supportive of us working within those constraints" (C6, emphasis added).

"In a nutshell it's [private SER] now much more proactive, much more positive and much more routine. I think 10 years ago if you went into a meeting with business and asked them about the environment or this or that, there was, for some companies, a degree of reticence in getting into that kind of discussion. Now it's routine business as usual, so actually the challenge now is not so much asking the basic questions, is actually having the probing questions and knowing the relevant and appropriate questions to ask... the dialogue is much more informed. We've got obviously much beyond - have you got a policy, to actually - what does that mean for you as a business and where is it building your business reputation, what are the risks, how are you managing them. So it's now a much more informed debate than it was I think 10 years ago" (I10, emphasis added).

There was a feeling among the company interviewees that the level of questioning in private SER had matured, the number of topics covered had lessened and the dialogue had become more focused,

"2 years ago it [private SER] was a massive shopping list (all laugh) that never once did we manage to cover all of the issues, but ... in general, they've become more focussed conversations, hard to say how many topics but it's probably no more than half a dozen maximum. Sometimes it may be just one or two issues or one issue may dominate the meeting and then it'll just be a couple of quick questions on other topics" (C7, emphasis added). 
Our interviewees appeared to pinpoint the most significant change to one/two years before the interviews, i.e. about 2006/2007. This seems to represent a watershed in the extent and nature of private SER. Indeed, the interviewees perceived there was a growing acceptance among companies and investors that social and environmental issues are in fact financial issues and are material. ${ }^{17}$ Indeed, they suggested that social and environmental issues are no longer perceived as 'non-financial' issues but as financial in nature. This is a sea change in perceptions relating to issues which were traditionally deemed 'soft' or 'qualitative,

"climate change for business isn't an environmental issue; it's a financial issue" (C1, emphasis added).

"I think too that people are really understanding that [environmental risk] is a material risk for investors, that this isn't some 'willy nilly', 'pie in the sky' thing ... they're [environmental issues] becoming more material... because oil is approaching record highs, because we have a cap and trade system in Europe ... because the polar ice cap is melting and it's literally material now" (I1, emphasis added).

The interviewees' comments suggest that the recently emerged, but hitherto separate, responsible investment logic is starting to don the appearance and terminology of the dominant finance logic in institutional investment. Indeed, the emerging responsible investment logic is enshrined in the business case. Materiality of social and environmental issues appeared important from a risk perspective as the interviewees discussed the financial effect of social and environmental issues on company value in terms of the downside rather than the upside,

"I think very few companies are actually given credit for doing anything particularly positive but they will suffer the consequences of doing something wrong" (C15, emphasis added).

Our interviewees considered that social and environmental issues were material to their businesses, with one company estimating materiality thresholds at $£ 50 \mathrm{~m}(\mathrm{C} 1$, $\mathrm{C} 3)$ and another at $£ 10 \mathrm{~m}(\mathrm{C} 2)$,

“... well they're [social and environmental issues] hugely material, they are hugely significant." (C3, emphasis added).

“...If you're dealing with a company where actually you've got industrial process of a significant type then you've got to conform to environmental legislation. Your risks of not conforming to that legislation are really significant to the extent of people losing licence to actually operate. So yes they are very material" (C15, emphasis added).

Interestingly, a legitimacy theory explanation for environmental risk management is prevalent here, as companies are clearly concerned about their license to operate as well as financial penalties attached to losing this license. The view that social and

\footnotetext{
${ }^{17}$ Only one outlier (C13) felt that social and environmental considerations were not material.
} 
environmental issues constitute a financial risk was prevalent throughout the interviews,

"I think what has changed is the way that investors have started to frame those issues in relation to investment decisions. So it's no longer just the case of, 'are you complying with environmental legislation?', it's more, 'how are you going to take advantage of the low carbon economy and the opportunity that presents to sell products?'. So it's a huge switch in thinking, so there's on one hand a risk to be controlled, on the other its very much, how are you going to maximise this opportunity" (C2, emphasis added).

Again the perceptions of the corporate as well as the investment community seem to have shifted such that social and environmental issues are now acknowledged as being material.

"I've spent a couple of hours with [investment institution] about a month or so ago and they are starting to look at SRI far more seriously and they are plotting a lot of businesses and we're included in that" (C3).

These comments support the notion of an emerging responsible investment logic but one which is deeply rooted in the business case, materiality and financial risk/risk management. Indeed, the evidence from the interviews supports the emergence of a responsible investment logic as suggested in Table 1 and provides an image of the ways in which private SER has developed as a primary mechanism of responsible investment, a unique characteristic of UK institutional investment.

One driving force behind the increasing integration of private SER into mainstream institutional investment identified by the interviewees was the growing importance of climate change to both companies and their core institutional investors,

"...so we often get - can we come and meet just to talk about climate change, we want to understand your point of view" (C7).

"climate change is a genie out of the bottle and it's such a global issue its effects are enormous" (C8, emphasis added).

"I've seen the emphasis on the areas of climate change and global warming has significantly increased in the last 3 to 4 years, it's come almost to the head of the list of issues that they're dealing with" (C11, emphasis added).

Solomon et al. (2011) showed that institutional investors were focusing on the financial risks and opportunities related to climate change in their investee dialogue. From the perspective of the extant neoinstitutional literature, climate change may be perceived as a jolt or significant exogenous change which has caused a shift in institutional logic within the institutional investment community, "Institutional systems undergo change for both external and internal reasons. Exogenous change may be occasioned by disruptions occurring in wider or neighboring systems ... that 
destabilize existing rules and understandings" (Scott, 2008, p.437). The growth of private SER has clearly been spurred on by increasing concerns about climate change,

"I think it [private SER] will grow, dialogue on these sorts of issues, particularly as environmental social problems become a bit more of a mainstream issue, just because they become more of a societal issue" (I13).

Investors discussed changes in society's attitudes towards social and environmental issues as a result of increased awareness of potentially catastrophic problems such as global warming. Such changes may be interpreted as shifts in societal attitudes and both companies and investors are struggling to adapt to these changes within their institutional settings. Such shifts in societal expectations can drive shifts in institutional logics.

\section{(ii) Emerging integrated private reporting}

Our interviewees provided evidence of a merging of the private SER process with private financial reporting also the involvement of mainstream fund managers and senior corporate directors in private SER meetings. Such merging of these two hitherto separate forms of private reporting indicates, in our view, the emergence of integrated private reporting. When asked to what extent they felt that material social and environmental issues were being integrated into mainstream financial one-on-one meetings, one company representative said,

"There are mainstream investors and mainstream investor representatives who are starting to ask questions" (C12).

The investors we interviewed were keen to integrate private SER into private financial one-on-one meetings:

"Yes to date most of mine [meetings] are purely devoted to social and environmental issues but going forward, we're trying to get the mainstream analysts and fund managers involved in it. They have oneon-one meetings all the time on financial issues so the idea is that maybe we might get one or 2 questions at the end on social and environmental issues" (I2)

The interviewees indicated that social and environmental considerations are increasingly discussed in 'mainstream' meetings (i.e. private financial reporting) and questions on social and environmental issues are being increasingly asked by mainstream fund managers,

"A lot of fund managers now incorporate elements of it [social and environmental issues] as part of their discussions with you. However, often you meet only with SRI specialists at that fund as well as at a separate meeting. So I can think of a couple of institutions that we've met recently where we initially had a meeting with a [mainstream] fund manager who incorporated small elements of SRI in the discussion but then a couple of weeks later the company also met the SRI specialist so 
that all elements of it were covered for that fund as a whole" (C16, emphasis added).

We interpret these changes and pressures for change as a shifting of institutional logic, as separate private SER is continuing but the dividing line between it and 'mainstream' private financial reporting is starting to blur, as social and environmental issues are increasingly discussed within the context of private financial reporting. The emerging rival logic is becoming integrated into the dominant logic. It is as if private SER is slowly being subsumed into private financial reporting,

"I think in the past it's [quantity of social and environmental issues into mainstream institutional investment] probably been quite limited but now ... that relationship is definitely growing and I think certainly for some funds, fund managers can't make decisions about investing in a company without approval from the SRI team to say that, yes this meets their criteria around whatever their SRI agenda might be as well." (C16, emphasis added).

When asked specifically whether social and environmental issues were present on the agenda of mainstream financial one-on-one meetings, interviewees indicated that they were and that this was a very recent development,

"The answer is yes and no, but two years ago, no it wouldn't have been" (C1)

“... as regards climate change, it will be quite a significant proportion of the [mainstream private financial reporting] agenda now..... when we're thinking of how we explain a new investment, more so now than it ever has been, we will be looking at the social and environmental aspects that go alongside that, that will give a broader picture of what we're trying to do" (C1, emphasis added).

The interviewees explained that in meetings with the mainstream fund managers social and environmental issues are discussed,

“.... probably up to about a year ago it would have only been the SRI person or the person that was interested in governance. That changed at the start of this year [i.e. 2008] and now the big [mainstream] fund managers are asking questions about climate change. Now it's interesting to know where they're getting their intelligence from; it's almost certainly from the SRI fund manager providing it internally and then coming back down through the mainstream route" $(\mathrm{C} 1$, emphasis added).

This provides an interesting insight into the workings of the information process, or at least the companies' perceptions of this process. It is notable that the word 'big' is used to refer to what are 'mainstream' fund managers, as if SRI managers are considered 'small'. This suggests that companies may take the 'smaller' SRI managers less seriously than the 'big' ones. Consequently it is likely that if the mainstream fund managers are starting to ask questions about ESG issues then companies will take more notice. Again, speaking of the integration of social and 
environmental issues into private financial reporting there was a distinct increase in especially climate change information discussed in this previously exclusively 'financial' context,

"....I think there is no doubt that environmental issues, the impact of climate change and so on, now feature in discussions in a way that perhaps, 5 or 6 years ago they didn't" (C5)

Investors discussed the increasing integration of social and environmental issues into financial meetings and also into financial portfolio management models

"I think the biggest evolution that we've seen at [investment institution] is we're now very much more focussed on very company specific integrated engagements with our portfolio managers around how these issues impact strategy and where the company's going with meetings at senior board level that feed directly into investment decisions. Can all these issues be quantified all the time? No, but they do feed into the mental models that our portfolio managers have of companies, so that's still integration. So our evolution has been very much more on making sure these things are integrated" (I3, emphasis added).

Indeed, the investors provided substantial evidence of increasing integration of social and environmental considerations into the mainstream investment process,

"My role is looking for the SEE [social, ethical and environmental] factors that are important and are impacting both balance sheets, to make sure the analyst knows about these and then they themselves can look at them and assess them on company specifics. You can call it mainstreaming if you like but it's more just integrating what used to be 2 separate things they're not anymore because they are real and they are causing opportunities and they're causing risks that need to be managed and it's just part of assessing a company now and analysing a company" (I6, emphasis added).

The increasing appearance of mainstream fund managers in private SER also indicated progressive integration of private SER into mainstream institutional investment,

"... we'll be meeting with the SRI people but they will bring the fund managers in sometimes. So not always but quite often they will bring the fund manager into the meeting" (C6, emphasis added).

The interviews with the investors provided insights into why they sometimes included mainstream fund managers in private SER,

"We also have the equity analyst and fund manager involved when it's an important meeting" (I15).

As well as ESG issues being integrated increasingly into private financial reporting, there is an increasing incidence of senior directors attending private SER, rather than 
just the CSR managers as has been the case previously. A greater focus on corporate strategy also indicated a progressive integration of private SER into the mainstream consideration of corporate performance,

"What I think has changed is increasingly those sessions [private SER] have now become truly face to face, true question and answer sessions, our senior team devoting time to sit with them" (C18, emphasis added).

"the quality of response typically that we get from management of companies and the board of companies has improved significantly. We find typically the Chief Executives and Chairs and senior independent Non Executive Directors are better placed to answer our questions in a way that they would have deferred before to their CSR manager, if they existed" (I16, emphasis added).

The companies we interviewed described a more continuous dialogue on social and environmental issues. The companies explained that they were more conversant with social and environmental issues and could talk about them more easily in private SER than before,

"I think when we started off on this route looking at more of the social aspects and integrating them into the environmental stuff, we did quite a lot of preparation, we just don't do that now because we've got a team who know this stuff inside out ..." (C1, emphasis added).

Senior management and directors are now expected to be conversant with social and environmental issues and answer questions in investor meetings with investors which they were not before,

“... corporate governance, health \& safety, environment, these are all reached at board level; the board will also be considering those, there'll be a lot of responsibility there so it's really at the top level. It's certainly not a case where the CEO is unaware of CSR; he has to be aware and he is fully aware, so it's top level down.... we do have some investors, some we've met recently, who will be very much focused on finance but they also ... will invest simply in companies that have a good corporate governance attitude or good social attitude or consider the environmental impact as well" (C10, emphasis added).

"our CEO ... sits on our board CSR committee anyway so he can handle lots of questions" (C12, emphasis added).

\section{(iii) Resistance to private SER and the responsible investment logic}

Although our interviewees identified a number of areas of resistance to private SER and to the apparent ongoing increase in engagement on social and environmental issues, the general trend appeared to be that resistance was diminishing across the board. The linking of ethics/responsibility with finance is likely to meet with resistance in a similar way to the predicted resistance to linking health and money in 
health reform (Broadbent et al., 2001). ${ }^{18}$ It seems from our interviews that the analyst community were resistant to the integration of private SER into mainstream institutional investment. Integration of social and environmental information seemed to be coming through the analysts' role although very slowly. Indeed, resistance to integration of social and environmental information into mainstream institutional investment seemed to arise principally from the financial analysts' community.

"my sense is that even in those 2 years, things have changed quite dramatically but it is in a more indirect, subtle way, we're still not getting the mainstream analysts asking those direct questions of the executive team, but they are increasingly coming through me and certainly I've seen calls for more engagement and I guess a greater maturity in the type of question that's being asked ..... So I'd say even in the past 2 years, I've sensed a growing maturity in what analysts are asking...but it's very difficult for us, from a corporate point of view, what is driving that; whether that is indeed just that the SRI community is evolving as opposed to quite separate or indeed whether there's this crossover with the mainstream and you're getting greater integration; I'd like to think that's what is causing it, but again it's hard to see direct evidence of that; it's mostly more indirect, conversations with the analysts, the brokers etc". (C7, emphasis added)

Similarly, our investor interviewees explained that financial analysts and fund managers had had no interest in ESG issues but that this was beginning to change, there is still an unwillingness among the analyst community to engage on ESG issues,

“... if all analysts put equal value on that kind of thing [social and environmental problems within companies] then it could actually be a fundamental driver in the value of a stock - but they don't yet, they're all marginal but I hope that maybe that will change" (I5)

Analysts present resistance as they are much slower to integrate issues than the buyside investors and fund managers. Is this a case of decoupling as the analysts are not taking social and environmental integration on board whereas actors more senior in the institutional investment and corporate communities are? Although fund managers and buy-side are increasingly asking questions in meetings about social and environmental concerns, analysts are not:

"The questions [on social and environmental considerations] weren't being asked by mainstream investors and to some extent they're still not being asked, probably to a large extent they're still not being asked by mainstream analysts" (C7, emphasis added).

Furthermore the influence and involvement of analysts has lessened,

".... the sell side is a route to the institutions as well. So there's the direct dialogue with our key shareholders and then there's the indirect through

\footnotetext{
18 "Whilst any group might well resist any change that is imposed upon it, the linking of health and money is particularly emotive" (Broadbent et al., 2001, p.566).
} 
the sell side ... in the last few years the importance of the sell side analysts as a channel has lessened; the large institutions have become more selfsufficient on their fundamental research and perhaps have been a little more demanding in meeting with the companies than they used to be. So less arms' length through the analysts now than it was maybe 10 or 15 years ago" (C17, emphasis added).

Earlier reliance on analysts by institutional investors meant that ESG was not integrated because the analysts were not taking it seriously. They were acting as a wall of resistance to integration. As investors rely less on analysts and more on their own research there is more integration of social and environmental information? As analysts become less important they are less of an obstacle to integration. Institutional investors (buy side) becoming more self-reliant. Neoinstitutional theory discusses the potential for incumbent structures and people to provide resistance to new mechanisms of (for example) governance and accountability within the institutional environment,

“... knowledgeable and experienced practitioners that inhabit many organizations will frequently attempt to resist the introduction of formal control practices by manipulating the application of such new practices, transforming them into means for advancing their respective interests..." (Fiss, 2008, p.396).

Such resistance by incumbent parties imbued with the dominant long-standing finance logic is consistent with the neoinstitutional academic literature which identifies resistance to organisational change (Broadbent et al, 2001). Resistance was interpreted as an 'uneasy truce' between rival logics of science care in medical education (Dunn and Jones, 2010). Despite the apparent rival nature of responsible investment logic and finance logic, the business case approach whereby ESG issues are starting to be perceived as material financial issues implies that these logics may gradually be seen not as antagonistic but rather supplementary to each other. ${ }^{19}$ Indeed, as analysts begin to appreciate the business case underlying the consideration of ESG issues in investment decisions their resistance to incorporating these factors is diminishing. Responsible investment specialists talked liberally about the resistance they struggled with among the financial analysts and financial fund managers,

"The real difficulty we have is proving to fund managers and hardened analysts that it makes any difference in terms of share price. But we are a business where it's core to what we do so it's taken as read this is what we do" (I10).

A chief reason why mainstream analysts discount ESG issues is because they tend to impact companies over the medium/long term whereas analysts' time horizons are short-term,

"And of course the City is very short term, it's only looking quarter to quarter. [FTSE100 company] is saying, 'this is going to save us money in

\footnotetext{
${ }^{19}$ Dunn and Jones (2010), quoting Peabody (1927) alluded to a similar situation in medical education regarding the apparently competing logics of care and science.
} 
2012 onwards, trust us; we're doing this now because of the long term'. For me as a long term investor that's fantastic; for hardened City analysts it's uninteresting because they want to know what's happening next quarter" (I10)

The investors we interviewed felt they had a role in educating analysts so that they would come to appreciate and understand the relevance of ESG issues to 'mainstream' financial investment management,

"What we're trying to do is get the fund managers and the analysts to have a basic, reasonable knowledge of these sorts of issues, or the risks in this area that companies might face. So if it's mining they might need to know some of the problems in certain countries and what climate change might mean for a mining company, whether there are water shortages or more hazardous mining techniques, things like that. So it's trying to bring them on a little bit so when they meet the companies, if they feel it's appropriate, they can ask the questions..... We're not trying to convert them into anything; we're just trying to better educate them so they're better able to do their jobs safely. As I say some are more responsive than others" (I19, emphasis added).

Similarly,

"Analysts [who] have purely focussed on fundamentals and may not have looked at this sort of thing - my role is to educate them a bit into why they need to be looking at these other bits and pieces as well, they might be important. It's tied into the question as well that we often get is would you ever divest from a company because of an SEE situation and our response to that is - not one thing - it's the same with the fundamental analysis, you wouldn't divest just because one financial ratio was out of alignment, you'd look at it" (I6, emphasis added)

The way in which the now initiated institutional investor community is 'educating' the analyst community is inherent in a shift in institutional logics. The resistance appears to be breaking down gradually with analysts taking an increasing interest in ESG issues as they are increasingly 'educated' by SRI specialists,

"I think that dialogue will become more formalised ... and it is already with the sell side analysts arranging more meetings on these [ESG] issues" (I15).

Indeed, some investors suggested that the analysts' resistance had broken down to the extent that they no longer viewed ESG separately but rather as part of the financial considerations,

“... increasingly they [ESG] are mainstream issues and for our own equity analysts, they don't see them as something that they should consider in addition to the financials; they look at it as part of the, in terms of - is this company a sustainable company? Is how it's managing its risks on SEE 
as effective as how it's managing its liabilities or its debts or whatever else" (I15).

As well as the analyst community, the companies themselves presented some resistance to private SER but again this resistance seemed to be diminishing. As with the analysts, neo institutional theory suggests that organisations will resist change and the growing private SER process represents a significant change in companies' relations with their institutional investors. Resistance from the corporate side to private SER and further integration of private SER appeared to arise from companies' fears about sharing forward looking information with their core investors. However, the interviewees suggested that these fears were diminishing over the past few years,

“..... there's always a risk about sharing future, forward looking statements with investors; there's always a debate in business about safe harbour and the extent to which you cannot get legal prosecution or institutional investors dropping you as a shareholding. But we've taken a bit more of a proactive view over the last 4 or 5 years that the more they understand what we're doing, actually the more confidence they have" $(\mathrm{C} 1$, emphasis added).

"For us there's the potential disadvantage of sharing information, being open and transparent to the extent that they see more risk to investing than others who are less transparent and again it's a very delicate balance to play...." (C7).

Despite the evident cost in time and resources of private SER, the companies seemed to feel that these were outweighed by the benefits of the meetings and discussion,

“... it [private SER] costs us money as an organisation because you have to employ people and they spend time doing it, but ... the cost for us of not doing it would be immense" (C6)

It seems that integration has accelerated significantly as these pockets of resistance have started to weaken.

\section{(iv) Perceptions concerning the future of private SER: Increasingly integrated private reporting}

We asked our interviewees how they perceived engagement and dialogue on social and environmental issues would evolve in the future and in what ways. The interviewees believed that private SER would continue to increase and also continue to become more integrated into mainstream institutional investment,

"I don't think there's any doubt this [private SER] will grow, as I said in terms of people's interests as they take a more holistic view of a company's performance" (C8, emphasis added).

"I think [private SER] it will continue to increase; my personal view would be over the next few years, environment will continue to become a 
bigger and bigger issue and we'll get more questions about it (C10, emphasis added).

The companies perceived climate change as the driving force behind the increasing integration of private SER into one-on-one meetings with mainstream institutional investors,

"Speaking to my area specifically, climate change, I think it is going to become much more mainstream because I think the world is moving towards sort of a global carbon standard and the cost of carbon will factor in almost everything we do ... So I see that as just doing nothing but growing and becoming a bigger part of that dialogue in the future" (C11, emphasis added).

"I think in the short term engagement and dialogue will increase, largely driven by the climate change agenda, largely driven by potential increases in legislation and how businesses will respond to them ... it'll become much more embedded, much more mainstream" (C18, emphasis added).

Interviewees also discussed a potentially paradoxical situation that as integration continues to increase private SER will actually diminish, as it becomes more part of the mainstream engagement and dialogue figured strongly in the discussions,

"If the current trend of discussions on climate change continues, interestingly enough I think the SRI community will actually reduce because I think the mainstream managers will start to understand what some of these issues are about ... we've worked terribly hard to embed it in our business to the extent that the vast majority of our board could probably talk quite eloquently on many of these issues .... So I think the engagement will decrease on social and environmental issues as specific [meetings] but they'll come through the mainstream" $(\mathrm{C} 1$, emphasis added).

"Well I'm making a fairly heavy bet that I'm right in that people will increasingly focus on this as a part of their normal mainstream investment. Normal mainstream investment means pulling out the 5 reasons to invest in a stock: The material risks and opportunities; where they fit with a responsible investment theme; it should be discussed with the company and it should be, when the CEO comes in, one of the questions we ask them - if it's not material it shouldn't be discussed. So yes I'd see it as moving more and more into part of the way my mainstream sector analyst talks to his broker and the way the broker speaks to IR and the way we speak to the company when they come in, rather than a separate SRI person speaking to the CSR team - much more involved in the mainstream" (I8, emphasis added).

"I think that in 10 years" time every investment is going to have to have some kind of ESG application and that's going to come because of the UNPRI [United Nations Principles of Responsible Investment] and some legislation" (I18). 
External change in climate will encourage institutional investors to align their activities with the expectations arising from societal expectations and ethos (Broadbent and Laughlin, 1991; Laughlin and Power, 1996).

"It's really important that my role is eventually phased out and the IR team are doing it as one joined-up story and they shouldn't need to be experts in climate change or carbon capture and storage or these things" (C7).

This feeling that the specialist roles in companies may disappear as ESG issues merge with financial issues was mirrored by the investor interviewees' views,

"I would like to hope that it just becomes, I suppose, my job, effectively null and void and that it becomes part of the mainstream. So I hope that it will become absolutely [integrated] and you'll have a set of questions on key performance areas from a financial perspective and in every meeting you have questions on how they're looking at environmental and social issues - that's what I would hope and I don't see any reason why that can't be" (I5, emphasis added).

From the investors' point of view this increasing integration of ESG into the mainstream could also imply the capture of ESG issues (now deemed financial) by the mainstream financial analysts and fund managers who previously resisted the responsible investment logic,

"I'd hope that even more issues would get mainstream and that the ESG dialogue won't be special meetings but will be part of the general roadshow. The interesting issue is whether we'll still be allowed to do it because for example climate change used to be pretty much our preserve now it's gone so mainstream that some of the mainstream analysts are almost saying - it's far too important for you guys, you little liberals to be faffing around! (both laugh) Yeah, I hope it would get more mainstream" (I20)

Such disappearance of separate private SER is suggestive of the integration and incorporation of the responsible logic of ESG into the dominant finance logic such that the finance logic of private financial reporting becomes inclusive of ESG issues and more holistic. This also reflects the shift in public sustainability reporting whereby the ultimate objective in its evolution appears to be the production of one integrated report which integrates material social and environmental issues into the mainstream report, making the production of separate sustainability reports unnecessary (IIRC, 2011). We present this optimistic outcome as scenario one in Figure 1.

Alternately, the merging of private SER and private financial reporting could represent a simulacrum of a hybridisation of institutional logics whereby private SER is effectively absorbed into private financial reporting losing its potential to effect change. This less optimistic, more sceptical vision is represented as scenario two in Figure 1. Neoinstitutional theory has been somewhat preoccupied with the notion of 
ceremonial or superficial conformity by organisations when faced with institutional pressures to change (Meyer and Rowan, 1977; Scott, 2008). Decoupling can arise where organisations are forced to adopt structural changes but 'decouple' them from actual practices by constructing practices which simulate genuine change (see for example Archel et al.'s findings for stakeholder engagement). The evolution of private SER could be interpreted in this light, as the meetings have been seen as opportunities for ritual and myth creation and appear to have little effect on investment decision making (Solomon et al., forthcoming). Such decoupling may be interpreted as a response to pressure for institutional change. A linked response is for organisations to "'internalise' the threat, incorporating new types of actors expert in dealing with these issues. The evidence provided in this paper could suggest that integrating SRI managers into private financial reporting may be a way of absorbing and neutralising the 'threat' from the responsible investment community rather than genuinely integrating the issues into the heart of financial private reporting processes. Certainly, the evolution of private SER with the development of a separate process running parallel to private financial reporting with the emergence since the late 1990s of SRI managers and SRI analysts resonates with the findings of earlier work (Hoffman, 1997). ${ }^{20}$ The emergence of new roles and actors can enhance the strength of the emerging logic or weaken it (Scott, 2008). From our findings, we can see that these responses are occurring but on the basis of our data we cannot yet establish whether these changes will lead to scenario one or scenario two.

Insert Figure 1 about here

\section{Concluding discussion}

This paper provides substantial evidence that integrated private reporting is starting to emerge. Interviews with representatives from FTSE100 companies and from UK investment institutions confirmed that a responsible investment logic has evolved in a relatively short space of time, with private SER developing as an important mechanism of responsible investment. Further, our findings highlight what may be interpreted as a hybridisation of institutional logics within the institutional investment community. Instead of remaining a marginal and separate element of institutional investment, our findings show that private SER is merging with private financial reporting. This merging appears to represent the integration of responsible investment into mainstream institutional investment. We suggest that this trend represents the emergence of integrated private reporting, mirroring a similar trend in the public reporting sphere. Our interviewees were directly involved in private SER and talked about the long-term changes in attitude within the institutional investment community in the private SER process. They noted resistance to this process of institutional change in attitude and behaviour from within the institutional investment community, most notably among financial analysts as well as from the corporate community. However, as the role of analysts in institutional investment weakens and as the analysts themselves begin to accommodate hitherto 'non-financial' considerations into their remit, the level of resistance seems to be diminishing. Traditional attitudes which prioritise the financial and marginalise the 'non-financial' seem less and less relevant to contemporary financial markets. This is the first paper which suggests the

\footnotetext{
${ }^{20}$ Hoffman (1997) found that environmental specialists were hired in new offices/departments within chemical organisations in order to cope with the demands from environmental lobbyists (Scott, 2008).
} 
emergence of integrated private reporting and thus makes a contribution to accounting theory as well as to the practice of private reporting. Further, a practical policy implication arising from the research could be the need for education of the financial analyst community in the materiality of ESG issues.

This paper seeks to advance studies in institutional theory by demonstrating the emergence of a coexistent responsible investment logic embodied in private SER and running in tandem with established private financial reporting meetings (i.e. the dominant finance logic in investment). Institutional logics has hitherto not been used as a means of interpreting the growth of responsible investment and private SER. Therefore, we feel that this paper contributes to the theoretical field of institutional logics by extending the application of this theoretical framework into a new area. Further, as private SER merges increasingly with private financial reporting it is possible that there is a shift from a dominant finance logic to an increasingly hybridised institutional investment logic which is holistic in nature featuring integrated investment considering both financial and ESG issues together in mainstream institutional investment strategy and decision-making. What we see, similar to the findings of Dunn and Jones (2010), may not be the replacement of the finance logic with the responsible investment logic but rather a metamorphosis of the institutional investors' perceptions from the dominant finance logic into a holistic logic within institutional investment and corporate governance. This emergence of a hybrid logic may also represent the coexistence of a logic of responsibility with the dominant finance logic is similar to findings for other institutional domains, for example, “.... plural logics co-evolve within a profession over time. We found that care and science logics coexist, moving through periods of balance and imbalance and residing in perhaps an uneasy tension that is not easily resolved in medical education" (Dunn and Jones, 2010, p.139). There are also similarities with the work of Lounsbury (2007) where the US mutual fund industry was found to have shifted from dominance by a trustee logic to a financial logic over time. Indeed we are seeing a reverse situation where the UK institutional investment industry is moving from a short-termist financial logic to a responsible logic with greater emphasis on the longterm. Such merging of logics could signal the emergence of integrated private reporting mirroring trends to produce integrated reports in the public reporting arena.

The apparent hybridisation of hitherto soft, qualitative factors with financial considerations may however be interpreted in a different manner. From an institutional theory perspective it is possible that a new, hybridised institutional investment logic may instead be simply the long-dominant finance logic dressed as something different. The growth of responsible investment (itself perhaps a euphemism to appease hardline investors) may be interpreted as the neutralisation of SRI and of any activist social and environmental agenda within the institutional investment community, originally aimed at transforming corporate behaviour. Taking a critical view, it is possible that the strategies of resistance to pressure from the responsible investment actors has been to redefine ESG in financial terms, to talk of materiality of social and environmental issues and to redefine terminology in order to apparently integrate RI into the mainstream. Such attempts by the mainstream institutional investment community may be interpreted as strategies of resistance to organisational change (Broadbent et al., 2001). The increasing involvement of senior directors and mainstream fund managers in the private SER engagement process may be more about absorption and neutralisation of the SRI agenda than about genuine 
integration. From this perspective, we may be witnessing absorption (Broadbent et al., 2001) of the responsible investment logic into the financial logic. This alternative and rather jaundiced view is nevertheless consistent with recent interpretations of stakeholder engagement processes as well as of the private social and environmental processes as ritual, myth creation and the institutionalisation of unaccountability (Archel et al, 2011; Solomon and Darby, 2005; Solomon et al., 2010). We feel that this alternative interpretation represents an extension of theoretical work in private reporting.

There are also other issues at work within the institutional investment community which could be playing a part in the apparent hybridisation of logics. The investors are keen to grow and maintain their client base and clients are currently attracted to investment institutions which appear to be responsible in a climate of increasing environmental awareness and concern for human rights. Such moves by the institutional investment community are likely to be in line with current expectations and consensus of UK society at large. By 'looking like' responsible investors, the institutions may be seeking to align their attitudes and activities with those of society at large. There are also tax incentives for companies to become more socially responsible. Further research is necessary to assess the extent to which this evident integrative process falls into scenario one or two. Further research is now required to explore the nature of the increasing integration through the eyes of other agents within the institutional investment community involved in this private SER process, for example analysts.

A possible explanation for this precipitous metamorphosis from financial logic to financial/responsible logic may be the growing societal awareness of climate change and of its substantial implications for the finance industry and financial institutions inter alia. Indeed, the rate of growth of the responsible investment agenda has increased intensely over the last ten years, as discussed throughout the paper. A 'jolt' as pervasive and global as climate change has perhaps accelerated the nascent institutional change within the investment industry and within the process of engagement and dialogue, "Environmental jolts highlight institutionalized assumptions about the environment, and reveal unexpected relationships between institutionalized practices, technologies, organizational forms, and outcomes that may not be apparent in times of stasis ... Jolts can prompt field-wide crisis, that is, perceptions by field actors (organizations, regulators, investors, customers, etc.) that fundamental outcomes are in contrast to expectations, and precipitate action intended to avoid dramatic negative outcomes" (Sine and David, 2003, p.186). The growing recognition that traditional, purely financial indicators are no longer sufficient for investors to value and appraise corporate performance and success is manifesting itself in new and emergent forms of dialogue between investors and investees which could be holistic, integrated and inclusive. Despite the pessimistic view of institutional change presented in scenario two, the strength of the underlying social movement and its success in infiltrating mainstream institutional investment may imply that the merging of private SER and private financial reporting could result in genuine change over time. "... the embedding of social movement discourse and practice within conservative institutional frameworks holds out the possibility of continued social change, albeit in much less visible and dramatic ways" (Lounsbury, 2001, p.52). 
Instead of responding to the perceived 'threat' of a growing responsible investment logic, by developing a genuinely holistic approach to institutional investment, it may be that the absorption of responsible investment into mainstream institutional investment represents a strengthening of the financial logic. By assimilating responsible investment mechanisms such as private SER into mainstream financial meetings and financial investment decision-making. To echo Greenwood and Suddaby (2006) bringing social and environmental issues into private financial reporting and into the heart of mainstream investment processes, investment institutions may in fact be rejecting the status quo of how to do things but at the same time the logic of shareholder value may remain untouched, or even strengthened, reinforcing the status quo of 'who' benefits (i.e. shareholders). Positive impacts on other stakeholders are likely to be coincidental by-products rather than intended consequences.

The way in which earlier forms of ethical investment have been overtaken by responsible investment which is embedded in the business case and in a shareholder value approach may be seen as an 'amoralising' 21 of traditional ethical investment and its roots in ethics and morality: responsible investment going forward may simply become financial investment with inclusion of ESG factors according purely to financial considerations. In this scenario, all ethical, philanthropic, social responsibility concerns are subordinated to financial considerations. This has certainly been supported by research into private meetings on climate change issues, as these were found to be dominated by a discourse of (financial-related) risk and opportunity.

To summarise, the merging of private SER with private financial reporting bears striking similarity to current attempts to develop integrated reporting in the public disclosure domain. ${ }^{22}$ Indeed, it seems that private reporting channels may be following public reporting channels by attempting to integrate sustainability information into the heart of mainstream, traditionally financial reporting processes. Or it may be that private reporting channels are leading public reporting in this area, causality is hard to identify. As for sustainability reporting, the change in discourse (adopting more financial terms to disclose sustainability information) within sustainability reports over time may reflect attempts by corporates to neutralise the sustainability agenda rather than genuinely engage with it (Tregidga and Milne, 2006). Similar shifts in discourse within the responsible investment environment, from a discourse of ethics (as pertaining to traditional ethical investment) to a discourse of risk, opportunity and shareholder value (the business case) may similarly be neutralising the original agenda for bringing greater responsibility into institutional investment via private SER. This neutralisation could, if not countered, signal the end of ethical and socially responsible investment. Further research is needed to assess the extent to which either of these scenarios are borne out by evidence.

\footnotetext{
${ }^{21}$ We thank Markus Milne for suggesting this interpretation of 'amoralising' when we presented the paper at the FRBC conference, July 2012.

${ }^{22}$ See Solomon and Maroun (2012) for a summary of the current attempts to develop integrated reports internationally.
} 


\section{References}

Ambachtsheer, J. (2005) 'Socially responsible investing - moving into the mainstream', 23 June, www.merceric.com

Archel, P., Husillos, J. and Spence, C. (2011) The institutionalisation of unaccountability: Loading the dice of corporate social responsibility discourse", Accounting, Organizations and Society, 36, 327-343.

Atkins, J. F. and Maroun, W. (forthcoming, 2014) South African Institutional Investors' Perceptions of Integrated Reporting, ACCA Research Report.

Blatter, J. (2003) "Beyond hierarchies and networks: institutional logics and change in transboundary spaces", Governance: An International Journal of Policy, Administration, and Institutions, 16(4), 503-526.

Boatright, J. R. (1999) Ethics in Finance, Foundations of Business Ethics, Blackwell Publishers, Oxford, UK.

Broadbent, J., Jacobs, K. And Laughlin, R. (2001) "Organisational resistance strategies to unwanted accounting and finance changes: the case of general medical practice in the UK", Accounting, Auditing \& Accountability Journal, 14(5), 565-586.

Broadbent, J. and Laughlin, R. (1991) "Recent financial and administrative changes in the NHS: A critical theory analysis", Critical Perspectives on Accounting, 2, $1-29$.

Cadbury Report (1992) Report of the Committee on the Financial Aspects of Corporate Governance: The Code of Best Practice, Gee Professional Publishing, London, December.

Castells, M. (2000) The rise of the network society, Blackwell, Malden, MA.

Di Maggio, P. \& W. Powell (1991) (Eds.), The new institutionalism in organisational analysis (pp. 1-40). Chicago: University of Chicago Press

Dunn, M. B. and Jones, C. (2010) "Institutional logics and institutional pluralism: the contestation of care and science logics in medical education, 1967-2005", Administrative Science Quarterly, 55(1), 114-149.

Fiss, P. C. (2008). Institutions and Corporate Governance. In R. Greenwood \& C. Oliver \& R. Suddaby \& K. Sahlin-Andersson (Eds.), The Sage Handbook of Organizational Institutionalism (pp. 389-410). Los Angeles, London: Sage.

Friedland, R. and Alford, R. R. (1991) Bringing society back in: Symbols, practices and institutional contradictions, in Powell, W. W. and DiMaggio, P. J., The New Institutionalism in Organizational Analysis, University of Chicago Press, Chicago.

Friedman, A. L. and Miles, S. (2001) 'Socially responsible investment and corporate social and environmental reporting in the UK: an exploratory study', British Accounting Review, 33, 523-548.

Giugni, M. (1998) "Was it worth the effort? The outcomes and consequences of social movements", Annual Review of Sociology, 98, 371-393.

Giugni, M., McAdam, D. and Tilly, C. (1999) How Movements Matter, University of Minnesota Press, Minneapolis, MN, USA.

Gond, J-P. and Piani, V. (forthcoming) "Enabling Institutional Investors' Collective Action: The Role of the Principles for Responsible Investment initiative", Business and Society.

Greenwood, R., \& Hinings, C. R. (1996). Understanding radical organizational change: Bringing together the old and the new institutionalism. Academy of Management Review, 21, 1022-1054. 
Gregory, A., Matatko, J. and Luther, R. (1997) ' Ethical unit trust financial performance: small company effects and fund size effects', Journal of Business Finance and Accounting, 24(5), 705-725.

Hancock, J. (1999) Making Gains with Values: The Ethical Investor, Financial Times/Prentice Hall, London.

Harte, G., Lewis, L. and Owen, D. (1991) 'Ethical investment and the corporate reporting function', Critical Perspectives on Accounting, 2, 227-253.

Henningsen, C. (2002) "Investing as if the World Really Mattered", Corporate Environmental Strategy, Vol.9, No.2, pp.163-171.

Hoffman, A. J. (1997) From heresy to dogma: an institutional history of corporate environmentalism, New Lexington, San Francisco, USA.

Holden-Meehan (1999) The Millennium Guide to Ethical and Environmental Investment, Holden-Meehan, Bristol.

Holland, J. B. (1998a) "Private Disclosure and Financial Reporting", Accounting and Business Research, Vol.28, No.4, Autumn, pp.255-269.

Holland, J. B. (1998b) "Private Voluntary Disclosure, Financial Intermediation and Market Efficiency", Journal of Business Finance \& Accounting, Vol.25, No.1\&2, pp 29-68.

Holland, J.B. and Doran, P. (1998) "Financial institutions, private acquisition of corporate information, and fund management", The European Journal of Finance, 4, 129-155.

Holland, J. and Stoner, G. (1996) 'Dissemination of price sensitive information and management of voluntary corporate disclosure', Accounting and Business Research, 26(4), 295-313.

The Integrated Reporting Committee of South Africa (IRCSA) (2011) Framework for Integrated Reporting and the Integrated Report. Available: www.sustainabilitysa.org.

International Integrated Reporting Committee (IIRC) (2011) Towards Integrated Reporting: Communicating Value in the $21^{\text {st }}$ Century, IIRC.

Integrated Reporting Committee of South Africa (IRCSA) (2011) Framework for Integrated Reporting and the Integrated Report, $25^{\text {th }}$ January, IRCSA

International Integrated Reporting Committee (IIRC) (2013) The International Integrated Reporting Framework, IIRC.

King Report, The (2009) King Report on Governance for South Africa, King Committee on Corporate Governance, Institute of Directors in Southern Africa, Parktown, South Africa.

Knowles, R. (1997) Ethical Investment, Choice Books, Marrickville, NSW.

KPMG (2011) International Survey of Corporate Responsibility Reporting, KPMG International Cooperative, November

Kuhn, T.S. (1996) The structure of scientific revolutions, originally published in 1962 , The University of Chicago Press Ltd., London, UK.

Laughlin, R. C. (1987) "Accounting systems in organisational context: A case for critical theory", Accounting, Organizations and Society, 12(5), 479-502.

Laughlin, R. (1991) "Environmental disturbances and organizational transitions: some alternative models", Organization Studies, 12(2), 209-232.

Laughlin, R., Broadbent, J. and Willig-Atherton, H. (1994) "Recent financial and administrative change in GP practices in the UK: Initial experiences and effects", Accounting, Auditing \& Accountability Journal, 7(3), 96-124.

Litvack, K. (2002) Using Index Funds to Meet the SRI Challenge", Pensions Week, 10 June, pp.26-27. 
Lounsbury, M. (2001). Institutional sources of practice variation: Staffing college and university recycling programs. Administrative Science Quarterly, 46, 29-56.

Lounsbury, M. (2002). Institutional transformation and status mobility: The professionalization of the field of finance. Academy of Management Journal, $45,255-266$.

Lounsbury, M. (2007). A tale of two cities: Competing logics and practice variation in the professionalizing of mutual funds. Academy of Management Journal, 50, 289-307.

Lounsbury, M., \& Crumley, Ellen T. (2007). New practice creation: An institutional approach to innovation. Organization Studies, 28, 993-1012.

Lounsbury, M., \& Ventresca, M. (2002). Social structure and organizations revisited. Research in the Sociology of Organizations, 19, 1-36.

Lounsbury, M., \& Ventresca, M. (2003). The new structuralism in organizational theory. Organization, 10, 457-480.

Lounsbury, Michael, Ventresca, Marc J., \& Hirsch, Paul M. (2003). Social movements, field frames and industry emergence: emergence: A culturalpolitical perspective on US recycling. Socio-Economic Review, 1, 71-104.

Lounsbury, M. (2008) "Institutional rationality and practice variation: new directions in the institutional analysis of practice", Accounting, Organizations and Society, 33, 349-361.

Luther, R. G. and Matatko, J. (1994) ' The performance of ethical unit trusts: choosing an appropriate benchmark', British Accounting Review, 26, 77-89.

Luther, R. G., Matatko, J. and Corner, D. C. (1992) ' The investment performance of UK "ethical” unit trusts', Accounting, Auditing \& Accountability Journal, 5(4), 57-70.

Mansley, M. (2000) Socially Responsible Investment: A Guide for Pension Funds and Institutional Investors, Monitor Press, Sudbury, UK.

Mallin, C. A., Saadouni, B. and Briston, R. J. (1995) ' The financial performance of ethical investment funds', Journal of Business Finance and Accounting, 22, 483-496.

McCann, L., Solomon, A. and Solomon, J. F. (2003) ' Explaining the recent growth in UK socially responsible investment', Journal of General Management, 28(3), $32-53$.

Meyer, J.W. and Scott, W.R., (1983) Organizational environments. Beverly Hills, CA: Sage.

Meyer, R. E. and Hammerschmid, G. (2006) "Changing institutional logics and executive identities: A managerial challenge to public administration in Austria", American Behavioral Scientist, 49(7), 1000-1014, March.

Mezias, Stephen J. (1994). Financial meltdown as normal accident: The case of the American savings and loan industry. Accounting, Organizations and Society, 19, 181-192.

Mizruchi, Mark S., \& Fein, Lisa C. (1999). The social construction of organizational knowledge: A study of the uses of coercive, mimetic, and normative isomorphism. Administrative Science Quarterly, 44, 653-683.

Ocasio, W. (1997). Towards an attention-based view of the firm. Strategic Management Journal, 18, 187-206.

Oliver, Christine. (1991). Strategic responses to institutional processes. The Academy of Management Review, 16, 145-179.

Peabody, F. W. (1927) "The care of the patient", Journal of the American Medical Association, 88, 877-882. 
Pensions Week (2002) "SRI Behaviour Monitor Launched", Pensions Week, 26th August, p.8.

Piani, V. (2011) "The role of investors' collaborative engagement to promote company sustainability disclosure: Case studies from the PRI clearinghouse platform", plenary lecture at the $23^{\text {rd }}$ International Congress on Social and Environmental Accounting, University of St. Andrews, 7-9 September.

Power, M. and Laughlin, R. (1996) "Habermas, Law and Accounting", Accounting, Organizations and Society, Vol. 21, No. 5, pp. 441-465.

PRI (Principles of Responsible Investment) (2011) Report on Progress, 5 years of PRI: An analysis of signatory progress and guidance on implementation, PRI.

Reay, T. and Hinings, C. R. (2009) "Managing the rivalry of competing institutional logics", Organization Studies, June, 30(6), 629-652.

Roberts, J., Sanderson, P., Barker, R. and J. Hendry (2006) "In the Mirror of the Market: The Disciplinary Effects of Company/Fund Manager Meetings", Accounting, Organizations and Society, Vol.31, pp.277-294.

Scott, W. R. (2008) "Approaching adulthood: the maturing of institutional theory", Theory \& Society, 37: 427-442.

Scott, R. \& Zald, M. N. (Eds.), Social movements and organization theory (pp. 7395). Cambridge, UK: Cambridge University Press.

Sine, W. D. and David, R. J. (2003) "Environmental jolts, institutional change, and the creation of entrepreneurial opportunity in the US electric power industry", Research Policy, 32, 185-207.

Solomon, J. (2010) $\left(3^{\text {rd }}\right.$ edn) Corporate Governance and Accountability, John Wiley \& Sons Inc., Chichester, UK.

Solomon, J. F. (2009) The Transformation of Socially Responsible Investment, chapter in Contemporary Issues in International Corporate Governance, Tilde University Press, Australia.

Solomon, J. F. And Maroun, W. (2012) Integrated Reporting: The Influence of King III on Social, Ethical and Environmental Reporting, ACCA Research Report, August.

Solomon, A. and Solomon, J. F. (1999) 'Empirical evidence of long-termism and shareholder activism in UK unit trusts', Corporate Governance: An International Review, 7(3), July, 288-300.

Solomon, J. F., Solomon, A. and S. D. Norton (2002) "Socially Responsible Investment in the UK: Drivers and Current Issues", Journal of General Management, Vol.27, No.3, Spring, pp.1-13.

Solomon, J. F. and L. Darby (2005) "Is Private Social, Ethical and Environmental Disclosure Mythicizing or Demythologizing Reality?", Accounting Forum, Vol.29, pp.27-47.

Solomon, J. F. and A. Solomon (2006) "Private Social, Ethical and Environmental Disclosure", Accounting, Auditing and Accountability Journal, 19, 4, 564-591.

Solomon, J. F., Joseph, N. L., Norton, S. D. and A. Solomon, "Impression management, fabrication and myth creation in private social and environmental reporting: insights from Erving Goffman", forthcoming in Accounting, Organizations and Society.

Solomon, J. F., Solomon, A. Joseph N. L. and Norton, S. D. (2011) "Private Climate Change Reporting: A Discourse of Risk and Opportunity?", Accounting, Auditing and Accountability Journal, Vol. 24, No.8, pp.1119-1148.

Sparkes, R. (2002) Socially Responsible Investment: A Global Revolution, John Wiley \& Sons, Chichester, UK. 
Suchman, M. C. (1995) Managing legitimacy: Strategic and institutional approaches, Academy of Management Review Vol.20. (3), p.571-610.

Suddaby, R. And Greenwood, R. (2005) "Rhetorical strategies of legitimacy", Administrative Science Quarterly, 50, 35-67.

Thornton, P. H. (1999) "Institutional logics and the historical contingency of power in organizations: Executive succession in the Higher Education publishing industry, 1958-1990", American Journal of Sociology.

Thornton, P. H. (2004) Markets from culture: Institutional logics and organizational decisions in higher education publishing, Stanford University Press, Stanford, CA.

Tregidga, H. And Milne, M. (2006) "From sustainable management to sustainable development: a longitudinal analysis of a leading New Zealand environmental reporter", Business Strategy and the Environment, 15, 219-241.

Wadswoth, G. (2002) "Holy Jocks Rock SRI Stocks", Pensions Week, 9th September, p.3.

Williams, S. (1999) 'UK ethical investment: a coming of age', Journal of Investing, Summer, 58-75.

Zijderveld, A. C. (2000) The institutional imperative: the interface of institutions and networks, Amsterdam University Press, Amsterdam. 


\section{Table 1}

\section{The Evolution of a Responsible Investment Logic in the UK}

\begin{tabular}{|c|c|c|}
\hline Date & Event & Contribution to responsible investment logic \\
\hline 1992 & Cadbury Report published & $\begin{array}{l}\text { First policy document to stress the importance of institutional } \\
\text { investor engagement with investee companies }\end{array}$ \\
\hline 1997 & Huntingdon Life Science & $\begin{array}{l}\text { UK institutional investors and later US investors pulled out of } \\
\text { Huntingdon Life Science over animal rights abuses }\end{array}$ \\
\hline 2000 & GRI guidelines launched & $\begin{array}{l}\text { First guidelines for sustainability reporting launched. They are } \\
\text { now in their fourth generation. }\end{array}$ \\
\hline 2001 & $\begin{array}{l}\text { FTSE4Good series } \\
\text { launched }\end{array}$ & $\begin{array}{l}\text { These UK SRI indices include companies which are rated as } \\
\text { performing well across ESG criteria }\end{array}$ \\
\hline 2001 & $\begin{array}{l}\text { Change to UK pension } \\
\text { fund law }\end{array}$ & $\begin{array}{l}\text { Mandatory requirement for all institutional investors to disclose in } \\
\text { the Statement of Investment Principles the extent to which, if at } \\
\text { all, they consider social, ethical and environmental issues in their } \\
\text { investment decision making }\end{array}$ \\
\hline 2002 & $\begin{array}{l}\text { Institutional } \\
\text { Shareholders' Committee } \\
\text { (ISC) Code published }\end{array}$ & $\begin{array}{l}\text { The Responsibilities of Institutional Shareholders and Agents: } \\
\text { Statement of Principles established a benchmark for institutional } \\
\text { investor practice in the areas of engagement and voting }\end{array}$ \\
\hline 2001 & $\begin{array}{l}\text { Association of British } \\
\text { Insurers' (ABI) SEE } \\
\text { reporting guidelines }\end{array}$ & $\begin{array}{l}\text { This set of guidelines indicated what SEE information institutional } \\
\text { investors would like to see disclosed }\end{array}$ \\
\hline 2000 & $\begin{array}{l}\text { Carbon Disclosure Project } \\
\text { (CDP) launched }\end{array}$ & $\begin{array}{l}\text { This global institutional investors' collaborative group asks } \\
\text { companies to complete an annual survey on carbon emissions and } \\
\text { related information. }\end{array}$ \\
\hline 2005 & $\begin{array}{l}\text { Freshfields Bruckhaus } \\
\text { Derringer Report } \\
\text { published }\end{array}$ & $\begin{array}{l}\text { Specified the consideration of ESG issues to be part of a pension } \\
\text { fund's fiduciary duty where: (a) there was a consensus among } \\
\text { pension fund members (b) where ESG issues were deemed } \\
\text { material }\end{array}$ \\
\hline 2006 & Stern Review published & $\begin{array}{l}\text { Stern Review stated scientific consensus on global warming and } \\
\text { had an immediate impact on society }\end{array}$ \\
\hline 2006 & $\begin{array}{l}\text { Revision of UK Company } \\
\text { Law }\end{array}$ & $\begin{array}{l}\text { Legal endorsement for companies to consider stakeholders in their } \\
\text { decision making }\end{array}$ \\
\hline 2006 & UN endorsement of PRI & $\begin{array}{l}\text { Endorsement of the PRI Principles by the UN provided them with } \\
\text { greater international profile }\end{array}$ \\
\hline 2007 & ABI revised guidelines & Revised guidelines alter terminology from SEE to ESG disclosure \\
\hline 2010 & $\begin{array}{l}\text { Stewardship Code } \\
\text { published }\end{array}$ & $\begin{array}{l}\text { ISC code adopted by the FRC as a code aimed to enhance the } \\
\text { quality of engagement between institutional investors and } \\
\text { companies }\end{array}$ \\
\hline 2010 & BP crisis & $\begin{array}{l}\text { High profile oil spill in Gulf of Mexico highlighted financial } \\
\text { nature of ESG risk }\end{array}$ \\
\hline 2010 & PRI Clearinghouse & $\begin{array}{l}\text { The establishment of the Clearinghouse Engagement Platform } \\
\text { marks a distinct step towards greater collaborative activism among } \\
\text { global institutional investors on ESG issues }\end{array}$ \\
\hline 2011 & $\begin{array}{l}\text { FairPensions Report } \\
\text { published }\end{array}$ & $\begin{array}{l}\text { Report specifies the need for pension funds to redefine fiduciary } \\
\text { duty to incorporate broader issues such as ESG. }\end{array}$ \\
\hline
\end{tabular}


Figure 1

Interpretation 1: Integrated Private Reporting

\begin{tabular}{|c|c|c|}
\hline $\begin{array}{c}\mathbf{2 0}^{\text {th }} \text { century } \\
\text { Long dominant finance } \\
\text { logic in institutional } \\
\text { investment } \\
\text { Private financial } \\
\text { reporting developing }\end{array}$ & & \\
\hline$\downarrow$ & & $2000-2007$ \\
\hline & & $\begin{array}{l}\text { Emergence of competing } \\
\text { responsible investment logic } \\
\text { Private SER developing as a } \\
\text { separate process distinct from } \\
\text { private financial reporting }\end{array}$ \\
\hline $\mathbf{y}$ & & $\mathbf{K}$ \\
\hline & $2007 / 8$ & \\
\hline & $\begin{array}{l}\text { Holistic logic, ESG integrated into } \\
\text { traditional finance logic indicating a } \\
\text { paradigm shift as non-financial issues } \\
\text { recognised as financial } \\
\text { Integrated private reporting emerges }\end{array}$ & \\
\hline & $\downarrow$ & \\
\hline & Future? & \\
\hline & $\begin{array}{c}\text { Institutional investment takes holistic } \\
\text { approach fully integrating ESG issues and } \\
\text { private SER disappears as a separate } \\
\text { process }\end{array}$ & \\
\hline
\end{tabular}


Figure 2

Interpretation 2: Absorption of responsible investment logic by dominant finance logic?

\begin{tabular}{|c|c|c|}
\hline $\begin{array}{c}\mathbf{2 0}^{\text {th }} \text { century } \\
\text { Long dominant finance logic in institutional } \\
\text { investment }\end{array}$ & & \\
\hline $\begin{array}{c}\text { Private financial reporting developing } \\
\boldsymbol{2 0 0 7 / 8}\end{array}$ & & $\begin{array}{c}\text { Emergence of competing institutional logic } \\
\text { of responsible investment } \\
\text { Private SER developing as a separate process } \\
\text { distinct from private financial reporting }\end{array}$ \\
\hline $\begin{array}{c}\mathbf{2 0 0 0}-\mathbf{2 0 0 7} \\
\text { investment logic: not genuine integration } \\
\text { Private financial reporting absorbs private SER }\end{array}$ & & \\
\hline $\begin{array}{c}\text { Future? } \\
\text { Private SER ceases to exist as a separate process: } \\
\text { institutionalisation of unaccountability? } \\
\text { Responsible investment neutralised }\end{array}$ & & \\
\hline
\end{tabular}

